presumably had not reached sexual maturity. Only one barnacle $(10 \mathrm{~mm})$ contained ripe egg lamellae.

No other hauls from the Rockall Trough have yielded examples of this partnership. This phoretic association presumably affords $T$. kaempferi protection without disadvantaging the crab.

\title{
Post-larval morphology of some northwest European ophiuroids
}

\section{Webb}

Department of Oceanography, University College, Swansea SA2 8PP, Wales

The early post-larval development of ophiuroids, in general, follows a similar pattern of disc and arm plate morphogenesis. Adult characteristics are developed at some stage in this period, but often well beyond metamorphosis. The transient post-larval morphology present in this intervening period, often differing markedly from subsequent stages, has generally poorly known taxonomic, ontogenetic and functional significance. A brief survey of the dorsal disc and arm morphology in the smallest free-living and settled post-larvae of a variety of N.W. European representatives of the order Ophiurae (Ophiura ophiura, O. albida, O. ljungmani, Ophiocten gracilis, Ophiomusium lymani, Acrocnida brachiata, Amphiura filiformis, A. chiajei, Amphipholis squamata, Ophiocomina nigra and Ophiacantha bidentata) serves to highlight and explore these aspects. The use of Scanning Electron Microscopy (SEM) proves invaluable in resolving such features.

Primary plate stereom is an intriguing early post-larval feature that may prove to have significance at various taxonomic levels. For example, a distinctive stereom of a regular pattern or round, craterlike fenestrations extending to the plate edge, is observed in the three Ophiura species examined and appears to be confined to the genus. Similarly the rounded pentagonal central primary plate and rectangular terminal plate may be other generic features.

Another plate stereom observed is the bordered type observed in Acronida brachiata, Amphiura filiformis and Ophiocten gracilis. In Acronida with $0.4-0.6 \mathrm{~mm}$ discs, the thicker central region has an open latticework while the region bordering the plate edge is thin, having its fenestrations partially infilled. Variations of this bordered plate stereom occur in the other two species, but in all cases such borders are confined to the primary plates. Other features of plate development are specific, such as the fenestration size in Ophiura or the unique spined stereom of Ophiomusium lymani. The functional and adaptive value of ophiuroid primary plate morphology is generally unknown.

The nature of the terminal plate of the recently-metamorphosed post-larva exhibits greater variation between closely-related species, as do other aspects of arm development (i.e. arm segment number, spine form and equality of growth), whose adaptive and functional value may be more readily seen. That allied species with similar adult ecological habit remain distinguishable, may suggest that 
functional demands of the post-larval stage in a species' life history (possibly quite different to the adult period) are quite important.

Differences in the relative rate of disc plate and arm development between some direct and indirect species and shallow and deep sea forms are tentatively suggested.

\title{
Preliminary observations on the near-bottom ichthyofauna of the Rockall Trough: a contemporaneous investigation using commercial- sized midwater and demersal trawls to $100 \mathrm{~m}$ depth
}

\author{
N. R. Merrett and J. Badcock \\ Institute of Oceanographic Sciences, Brook Road, Wormley, Godalming, Surrey \\ GU8 5UB, U.K.

\section{S. Ehrich} \\ Institut für Seefischerei der Bundesforschungsanstalt für Fischerei, Hamburg, \\ Germany \\ and
}

\section{P. A. Hulley}

South African Museum, Cape Town, South Africa

The continental slope both truncates the distribution of the oceanic meso- and bathypelagic ichthyofauna and provides the headquarters of a diverse assemblage of demersal fishes. While demersal forms are well adapted to such an environment, the morphology of pelagic species differs conspicuously and seems better suited to an open ocean habitat. Submersible observations, together with a small body of near-bottom closing net data and records of pelagic fish in stomachs of demersal species, mainly constitute the scant knowledge of the interactions of these distinct faunal elements.

In May, 1983, during cruise 58 of F.R.V. Walther Herwig (Institut für Seefischerei, Hamburg) preliminary investigations were made into the swimming layers of the near-bottom ichthyofauna of the Rockall Trough $\left(56^{\circ} 18^{\prime}-44^{\prime} \mathrm{N}\right)$ using much larger nets than employed hitherto. Over a five-day period, five demersal trawls were made on the Feni Ridge and six on the Hebridean Terrace at approximately $200 \mathrm{~m}$ intervals from $200-1000 \mathrm{~m}$ soundings, using a 200 foot bottom trawl (200' BT-nominal mouth opening $22 \mathrm{~m} \times 6 \mathrm{~m}$ headline height). In addition, nine Engels midwater trawl (1600 PT-mouth opening $30 \mathrm{~m} \times 20 \mathrm{~m}$ high) collections were made in similar localities (Feni Ridge-four; Hebridean Terracefive) and depths fished with the footrope (0) 3-18 (60) $\mathrm{m}$ above the sea bed, together with a set of mid-Trough samples from $100,400,700$ and $1000 \mathrm{~m}$ depth 